\title{
CONFISCATION AND CORPORATIONS IN CONFLICT OF LAWS
}

From I9I8 to I92I revolutionary committees of the R.S.F.S.R., which later became a republic of the Soviet Union, passed and enforced decrees purporting to dissolve Russian corporations, to confiscate their property, and in many lines of business to nationalize commercial and industrial enterprise. In many of the courts of the world, the question has arisen as to the effect of the confiscation upon property belonging to Russian corporations but recoverable abroad. The legal answer to this question depends on (I) the interpretation of the Soviet decrees in regard to the corporate entity; (2) the nature and situs of the property; and (3) the effect of anti-confiscatory policies in countries other than Russia. This question had been resolved in favor of the Russian corporations and stockholders and creditors claiming under them. The Soviet government, however, had one recourse left. It could assign by international negotiation its rights based on its confiscation decrees to a foreign government which could then sue debtors to Russian corporations found within its territory. The recent decision of the United States Supreme Court in United States v. Belmont ${ }^{x}$ suggests that the Soviet resort to diplomacy has met with partial success.

\section{I}

In the Belmont case, a Russian corporation of the imperial regime prior to I9I8 deposited a sum of money with a private New York banker. In IgI8 the Soviets enacted decrees dissolving the corporation and confiscating its property. In I933, the United States recognized the Soviet Union on terms ${ }^{2}$ which included an assignment from the Soviet Union to the United States of its claims against American nationals and a duty on the part of the United States to notify the Soviet Union of its collections. The United States, as assignee, sued, in the southern district of New York, the executor of the New York banker for the sum of money deposited by the Russian corporation. It was held ${ }^{3}$ on a motion to dismiss that, as against the executor and Russian creditors and stockholders, the United States can recover the sum, but American and probably non-Russian-foreign creditors and stockholders can set up defenses at Federal law against the United States; no defenses at New York law, however, will be available because the assignment from the Soviet Union to the United States has the status of a treaty. A minority ${ }^{4}$ of the court concurred only on

× 301 U.S. 324 (1937).

2 For text, see 28 Am. J. Int. Law Supp. No. I, Official Documents, 1o (r934); State of Russia v. National City Bank, 69 F. (2d) 44, 46 (r934). See also Anderson, Recognition of Russia, 28 Am. J. Int. Law 9o (I934); Jessup, The Litvinoff Assignment and the Belmont Case, 3 I Am. J. Int. Law 48r (1937).

${ }_{3}^{3}$ Sutherland, J., speaking for Hughes, C. J., McReynolds, Butler, Roberts, and Van Devanter, J. J., 30I U.S. 324, 325-333 (x937).

4 Stone, J., speaking for Brandeis, Cardozo, J. J., 3or U.S. 324, 333-337 (I937). 
the proposition that the United States can recover the sum as against the executor. A motion by the New York receiver of the Russian corporation to intervene in the case was refused, ${ }^{5}$ presumably without prejudice to later action against the United States. ${ }^{6}$

On the question of what defenses creditors and stockholders can raise against the right of the United States, the majority and minority opinions differ. The minority, refusing to discuss the possible status of the assignment as a treaty, declared the effect of the assignment was to pass to the United States no more than the Soviet Union had, and the executor had no standing to challenge that effect, but they added that if New York had a policy allowing "local" to prevail over "foreign" creditors, that state could refuse to enforce "external transfers to property within its borders."7

If the last clause of the Fifth Amendment is applied in its natural meaning, the deposit must first satisfy the claims of creditors and stockholders of the Russian corporation who are of any nationality other than Russian. ${ }^{8}$ The remainder will be handed over to the United States. Creditors will, of course, come before stockholders, and creditors whose claims arose from transactions in this country may come before creditors whose claims arose from transactions abroad.9 However, statutes of limitation, affecting claimants other than the United States, ${ }^{30}$ and natural dispersion of persons interested in the corporation over the twenty years since it ceased to do business suggest that the United States may in the end recover something on this claim and others like it.

The partial success in enforcing rights based on confiscation in the Belmont case has been regarded by commentators ${ }^{\mathrm{II}}$ as a surprising increase in the constitutional treaty-making power of the executive. An examination of the underlying problems in the conflict of laws reveals, however, that the result reached is not unjustifiable and renders the constitutional law difficulties intelligible and perhaps unimportant.

The legal routine in the Russian cases has not been illuminating: the Soviet decrees are enforcible only in Soviet territory; extraterritorial enforcibility in

5 United States v. Belmont, 300 U.S. 64 I (r936).

${ }^{6}$ The receiver was only custodian of the corporate property which was not impounded by court process. The rights of American creditors were expressly saved by the Belmont case. See Moore and Levi, Federal Intervention I, 45 Yale L. J. 565, 58r, 586, $5^{89}$ ( 1936 ).

${ }^{7} 301$ U.S. 324, 333-337 (1937).

8 ". . . nor shall private property be taken for public use without just compensation," U.S. Const., Art. V; see Russian Volunteer Fleet v. United States, 289 U.S. 48I (I930).

9 People v. Russian Reinsurance Co., 255 N.X. 4I5, I75 N.E. Ix4 (I93r); People v. Second Russian Ins. Co., 255 N.Y. 436 , I75 N.E. I2I (I93 r).

10 United States v. Guaranty Trust Co., 9I F. (2d) 898 (C.C.A. 2nd, I937), noted, 5 Univ. Chi. L. Rev. $3^{13}$ (1938).

rr Riesenfeld, The Power of Congress and the President in International Relations, 25 Calif. L. Rev. 643, 670 (1937); 5 I Harv. L. Rev. I62 (r937); 47 Yale L. J. 292 (1937); 23 Va. L. Rev. 955 (I937); 22 Minn. L. Rev. II4 (I937). 
foreign courts must rest on international comity; the comity does not require anything at all in a mandatory sense, certainly not enforcement of any foreign law contrary to the public policy of the forum; the confiscation of private property without compensation is the purport of the confiscation decrees and is contrary to public, capitalistic policy; the decrees, therefore, cannot be enforced in the states of the forum. ${ }^{\mathrm{I} 2}$

It might seem that uncompensated confiscation would be so anathematic to courts in capitalistic countries ${ }^{13}$ that no Russian confiscation would be under any circumstances recognized abroad. This, however, has not been the case. Where a chattel was in Russia at the time of the decree and subsequently removed, the validity of the confiscation decree has, except before recognition of the Soviet Union, ${ }^{14}$ been upheld. ${ }^{15}$ Since it is arguable that the policy against confiscation is equally strong regardless of where the chattel was at the time of the decree, it would seem that the clue to these cases lies not in policy of the forum but rather in jurisdiction of the confiscating state. If, then, there can be confiscation effective to create rights which will be recognized in foreign courts, the question is one of finding its requirements.

It is clear that when all the elements are local the decree will be recognized abroad. ${ }^{16}$ The problem arises when either the property or its owners is in the

${ }^{\text {I2 }}$ Sokoloff v. National City Bank, 239 N.Y. I58, I45 N.E. 9I 7 (1924); The Jupiter, [r927] P. D. r22, 250; Etat Russe v. Ropit, Cour de Cass., March 5, I928, 55 Clunet 674; Wilbuschewitz v. Ville de Zurich, Trib. Fed. (Swiss), July I3, x925, 53 Clunet I I10; Ginsberg v. Deutsche Bank, K. G., Berlin, March 3, 1925, I Ostrecht x63.

${ }_{3}$ For legislative policy against Soviet confiscation in New York, see N.Y.C.P.A. $\$ 169$-a, held unconstitutional in Sliosberg v. New York Life Ins. Co., 244 N.Y. 482 , 155 N.E. 749 (I927). But see N.Y.C.P.A. §977-b.

The most recent expression of judicial policy against Soviet confiscation can be found in Moscow Fire Ins. Co. v. Bank of New York and Trust Co., x6I Misc. 903, 294 N.Y. Supp. 648 (1937), in which the United States intervened on the strength of the Litvinov assignment, but the court evidently felt not bound by the Belmont case because New York courts had taken jurisdiction of the fund in question before the Litvinov assignment was negotiated. See United States v. Bank of New York and Trust Co., 77 F. 2nd. 880 (C.C.A. 2nd 1934).

As to Federal policy, see suggestion, 22 Minn. L. Rev. Ir4 (I937), that the Litvinov assignment may express a policy superior to Federal anti-confiscatory law. But see Const. Art. V.

${ }^{14}$ Luther v. Sagor, [r92I] I K.B. 456; Bounatian v. Société Optorg, Trib. Civ. Seine, Dec. 12, I923, 5 I Clunet 133 .

15 United States: Salimoff v. Standard Oil Co., 262 N.Y. 220, I86 N.E. 679 (1933); Banque de France v. Equitable Trust Co., 33 F. (2d) 202 (C.C.A. 2nd Ig29).

England: Luther v. Sagor, [I92I] 3 K.B. 532; Princess Paley Olga v. Weisz, [I929] I K.B. $7 \times 8$.

Gerniany: Caucasian Licorice Co. v. Katz, L. G., Hamburg, June 13, I924, I Ostrecht 165.

Italy: R. S. F. S. R. v. Romische Schwefelgesellschaft, Ct. of Cass., Italy, April 25, x925. I Ostrecht I 78 .

Switzerland: Dame P. v. S., Trib. Sup. Zurich, Dec. I8, I928, 57 Clunet II59, involving a debt treated as a chattel, not a chattel. See Nebolsine, Recovery of Foreign Assets of Nationalized Russian Corporations, 39 Yale L. J. II30, II54 (x930).

${ }^{16}$ Dame P. v. S., Trib. Sup. Zurich, Dec. $x 8$, Ig28, 57 Clunet II59. 
confiscating state at the time of confiscation. Where the property is tangible there is the old question of whether control over the owner's person or control over the property itself is the compelling factor. The general result in the Russian cases has been to recognize the confiscation if the chattel was in Russia at the time of confiscation decree, ${ }^{17}$ but not to recognize it if the chattel was outside at the time..$^{18}$ This result making the situs of the property dominant has several precedents ${ }^{\mathrm{x}}$ and analogies. ${ }^{20}$ Some analogies sustain the Russian cases.

Assignees in compulsory ${ }^{2 x}$ bankruptcy or insolvency proceedings, for example, can only reach the debtor's property abroad subject to attachment or assignment to local creditors either before ${ }^{22}$ or after ${ }^{23}$ the proceedings. Where there are local creditors or ancillary receivers, a receiver of a corporation does not

${ }^{17}$ Note 14, sitpra.

${ }^{88}$ The Jupiter, [1927] P.D. x22, 250; Etat Russe v. Ropit, Cour de Cass., March 5, x928, 55 Clunet 674 .

${ }^{29}$ South and Central American appropriation and confiscation. Hamilton v. Accessory Transit Co., 26 Barb. (N.Y.) 46 (I857); American Banana Co., v. United Fruit Co., 2r3 U.S. 347 (IgI8); Oetjen v. Central Leather Co., 246 U.S. 297 (Igr8); Shapleigh v. Meier, 299 U.S. $468(1936)$.

So with confiscation by belligerents, Frankel \& Co. v. L'Urbaine Fire Ins. Co., 25 I N.X. 243, x67 N.E. 430 ( $x 929)$; Wolf v. Oxholm, 6 Maule \& S. 92 ( $x 817$ ); Peru v. Dreyfus Bros. 38 Ch. Div. 348 (I888); Folliot v. Ogden, I H. Black. I23 (1789); Second Russian Ins. Co. v. Miller, 268 U.S. 552 ( 1924 ), except where a revolutionary belligerent power is not ultimately successful. Williams v. Bruffy, 96 U.S. I76 ( 1877 ).

Absence of a revolutionary situation apparently permits enforcement of a foreign statutory corporate reorganization having confiscatory effect. Canadian Southern Ry. Co. v. Gebhard, Iog U.S. 527 (I883); Hudson River Pulp Paper Co. v. Warner \& Co., 99 Fed. x87 (C.C.A. 2nd I900). A German statute, product of the National Socialist "revolution," requiring German debtors to foreigners to pay the debts to the German government was not enforced in the United States. Central Hanover Bank \& Trust Co. v. Siemens \& Halske Actien-Gesellschaft, I5 F. Supp. 927 (S.D. N.Y. I936).

${ }^{20}$ The penal decrees, statutory or judicial, of one nation have never been enforced in the courts of another nation. Rosa Catana v. Potocki, Trib. Civ. Seine, May 7, x873, 2 Clunet 20; Lecouturier v. Rey, [r9I0] A.C. 203; Baglin v. Cusenier Co., 22I U.S. 580 (r9ro); Duc de Cambridge v. Duc de Brunswick, Cour Royale, Jan. 16, I836, [I836] Sirey II 70, 78 .

${ }^{21} \mathrm{~A}$ prior voluntary assignment by a debtor apparently has universal validity. Crapo v. Kelly, r6 Wall. (U.S.) 6ro (1872).

$\approx$ Clark v. Willard, 292 U.S. II2 (1933), 294 U.S. 2IX (1934).

${ }_{23}$ Harrison v. Sterry, 5 Cranch (U.S.) 289 (I8og).

For other types of transfers which defeat prior insolvency proceedings, see: Mitchell v. Banco de Londres, r92 App. Div. 720 , r83 N.Y. Supp. 446 (1920); Holmes v. Remsen, 20 Johns. (N.Y.) 229 (I822); Lessee of McCullough's Heirs v. Rodrick, 2 Ohio 235 (1826).

The English courts, on issuing a compulsory order for winding up a corporation whose principal assets are abroad, apparently expect the order to receive full enforcement abroad. In re General Co., L.R. 5 Ch. App. 363 (I870); In re Madrid-Valencia Ry. Co., Ig L. J. Ch. (N.S.) $260(1850)$. This expectation suffered early disappointment in the United States. Harrison v. Sterry, 5 Cranch (U.S.) 289 (I809). 
have power ${ }^{24}$ to collect chattels ${ }^{25}$ or to transfer assets ${ }^{26}$ lying in a foreign state but belonging to the corporation whose liquidation he is authorized to supervise. A statutory successor to the assets of a corporation may, however, have such power. ${ }^{27}$ Equitable or statutory mortgage foreclosure ordinarily ${ }^{28}$ does not affect land situated in a foreign state, ${ }^{29}$ nor does probate of a devise. ${ }^{30}$ Distribution of property by the law of intestate succession at the intestate's domicil does not affect his land in a foreign state. ${ }^{3 \mathrm{x}}$

These examples are analogical to the Soviet confiscation decrees because a judgment or decree of a court has set in motion the state's executive implements of coercion and force which can be effective only within and not beyond the boundaries of the state. So the Soviet decrees, although they purported to be legislation, were orders to Soviet committees setting in motion a standard, often violent, revolutionary procedure achieving effective dissolution of Russian corporations and confiscation of their assets within Soviet territory..$^{2}$

Other analogies, however, lend some force to an argument that the Soviet decrees might be effective beyond the Soviet boundaries. Courts of equity have granted decrees in personam ordering the conveyance of foreign land ${ }^{33}$

${ }^{24}$ The rule in the Federal courts is a strict territorial limitation on the powers of receivers. Booth v. Clark, I 7 How. (U.S.) 322 (1854); Laugblin, The Extraterritorial Powers of Receivers, 45 Harv. L. Rev. 429, 436-438 (I932).

${ }_{25} 3$ Beale, Conflict of Laws $1574^{-1575}$ (1935); Rest., Conflict of Laws $\$ \S 535,545,546$ (1934); Goodrich, Conflict of Laws 445-447 (1927); Stumberg, Conflict of Laws 424-426 (I937).

${ }^{26}$ Unless the receiver possesses a negotiable instrument or certificate representing the asset. 3 Beale, Conflict of Laws $x 576$ (1935); Rest., Conflict of Laws $\$ \$ 547,548$ (1934); Stumberg, Conflict of Laws 426 (I937).

${ }^{27} 3$ Beale, Conflict of Laws 5588 (I935); Rest. Conflict of Laws, $\S 567$ (I934); but see Clark v. Williard, 292 U.S. II2 (r933), 294 U.S. 2 II (I934).

${ }^{28}$ Where foreclosure of far-flung properties is sought to secure an issue of corporate bonds, a state which can serve both mortgagor and trustee can compel them to join in the foreclosure deed. 2 Beale, Conflict of Laws 948 (1935); Rest., Conflict of Laws $\S 97$, Comment c, $\S 449$ (2) (I934).

${ }_{29} 2$ Beale, Conflict of Laws 947 (I935); Rest., Conflict of Laws $\$ 97$, Comment c, § 227 (I934).

${ }^{30} 2$ Beale, Conflict of Laws 969-97I (1935); Rest., Conflict of Laws § 249 (1934); Stumberg, Conflict of Laws 407-408, Ioo (1937).

${ }^{3 x} 2$ Beale, Conflict of Laws 965-966 (x935); Rest., Conflict of Laws $\S 245$ (I934); Stumberg, Conflict of Laws 376-378 (r937).

${ }^{32}$ See Wohl, The Nationalization of Joint Stock Banking Corporations in Soviet Russia, - 75 U. of Pa. L..Rev. 385, 527, 622 (1927) for a description of the revolutionary procedure in the Soviet Union. For typical decrees, see Nebolsine, The Recovery of the Foreign Assets of Nationalized Russian Corporations, 39 Yale L. J. II3O, n. 2 (I930) and Russian C. \& I. Bank v. Comptoir d'Escompte de Mulhouse, [1925] A.C. II2, I 20-I23.

${ }^{33}$ See generally, I Beale, Conflict of Laws 4I7-422 (I935); Rest., Conflict of Laws § 97, Comment a and illustrations (x934); Stumberg, Conflict of Laws 95-96 (x937). 
when they have before them a defaulting trustee, ${ }^{34} \mathrm{a}$ defaulting contractor, ${ }^{35}$ or a person who obtained the property by a fraudulent device..$^{36}$ The compulsory deed resulting from such an order will be upheld where the land is because the compulsion was legal..$^{37}$ This line of cases is particularly strong because land is peculiarly subject to local law..$^{38}$ Aided by favorable construction, there are some striking parallels to the situation in many of the Russian cases. The Soviet Union had the Russian corporations within its jurisdiction; it regarded those corporations as defrauders and defaulters by the standards of the new order of communism; confiscation was legal compulsion in Russia; the confiscation decrees, although they have been construed otherwise, are inclusive enough to be construed as orders to convey foreign property to the Soviet government. ${ }^{39}$ But objections are readily discoverable. The mere statement of the parallels is enough to show that a non-Russian court could hardly be expected to be so generous on questions of construction. Further, there is no evidence that such conveyances were actually made..$^{\circ}$ Finally, local anti-confiscatory law or policy is a handy shield against application of Russian law even if it were found the proper law. ${ }^{4 x}$

Considering the Russian cases and their analogies in respect to tangible property located abroad, it seems that recognition of the territorial limitation upon a state's executive power is the real basis for refusal of foreign states to give the confiscation decrees extraterritorial force, if a legal rationale for the Russian cases must be found.

Where the property is intangible as in the Belmont case, the same approach may be used. Thus, if the situs of the intangible was in Russia at the time of the decrees, the decrees are effective; ${ }^{2}$ if it was outside Russia, the decrees are not effective. This seems to be the view in the Russian cases. ${ }^{43}$ However, the

34 Clark v. Towa Fruit Co., 185 Fed. 604 (C.C.D. Mo. IgIr).

35 Wrightsville Hardware Co. v. Assets Realization Co., I59 App. Div. 849, I44 N.Y.S. $99 \mathrm{r}$ (Igז3); Sutphen v. Fowler, 9 Paige (N.Y.) $280(\mathrm{r} 84 \mathrm{r})$.

${ }^{36}$ Massie v. Watts, 6 Cranch (U.S.) I48 (I8Io).

37 I Beale, Conflict of Laws 422 (1935).

${ }^{8} 8$ Clark v. Graham, 6 Wheat. (U.S.) 577 (I821); Swank v. Hufnagle, xII Ind. 453, I2 N.E. 303 (I887); Sell v. Miller, II Ohio State 33I (r860).

39 Note 32, sitpra.

to See Bullock v. Bullock, 52 N.J. Eq. 56r, 566,30 Atl. 676, 677 (r894).

4 But American courts have gone further in this type of case by formulating decrees implicitly requiring acts done on foreign territory. Salton Sea Cases, I72 Fed. 792 (C.C.A. gth Igog); see Vineyard, etc., Co. v. Twin Falls, etc., Co., 245 Fed. 9 (C.C.A. gth 1927), 3 I Harv. L. Rev. 646 (Igr8); $c f$. I Beale, Conflict of Laws 433-434 (I935).

42 Dame P. v. S., Trib. Sup. Zurich, Dec. 18, 1928, 57 Clunet $x \times 59$.

43 United States: Sokoloff v. National City Bank, 239 N.Y. I58, I45 N.E. 917 (1924); James \& Co. v. Second Russian Ins. Co., 239 N.Y. 248 , 146 N.E. 369 (1925); Volgakama JointStock Co. v. National City Bank, 240 N.Y. 368 , I48 N.E. 552 (I925); Vladikavkazsky Ry. Co. v. New York Trust Co., ${ }_{26}{ }_{3}$ N.X. 369 , 189 N.E. 456 (1934); Moscow Fire Ins. Co. v. Bank of 
formula is not quite so easy to apply. There are at least eight different views -all of them somewhat objectionable-as to the situs of a debt. ${ }^{44}$

It is situated at the creditor's domicil for purposes of taxation by the state benefiting by the taxation; ${ }^{45}$ or at the business situs. $4^{6} \mathrm{It}$ is situated at the debtor's domicil for purposes of escheat by the state benefiting by the escheat.47 It is situated where the debtor to the principal debtor can be found for purposes of garnishment by the state which has a law providing for the attachment of such a debt to be upheld..$^{8}$ In the Russian cases, debts with any foreign con-

New York and Trust Co., I6I Misc. 903, 294 N.Y. Supp. 648 (1937); Day-Gormley Leather Co. v. Nat'l. City Bank, 8 F. Supp. 503 (S.D. N.Y. x934); of. Dougherty v. Equitable Life Assur.:Soc., 266 N.Y. 7r, I93 N.E. 897 (I934).

England: In re Russian Bank for Foreign Trade, [I933] Ch. D. 745; Russian C. and I. Bank v. Comptoir d'Escompte de Mulhouse, [I925] A.C. II2; Banque Internationale v. Goukassow, [x925] A.C. I5o; First Russian Ins. Co. v. London \& Lancashire Ins. Co. [1928] Ch.D. 922; Woronin v. Huth \& Co., unreported K.B.D. decision, 55 Clunet 756 (1928); Buerger v. New York Life Assur. Co., 43 T.L.R. 60 I (I927); of. Perry v. Equitable Life Assur. Soc., 45 T.I.R. 468 (1929).

France: Société d'Assurance Phénix Espagnol v. Cockerill, Cour de Cass., July 4, 1933, 6r Clunet 662; Teslenko v. Banque Russo-Asiatique, Cour de Paris, June 22, 1929, 56 Clunet I I Io; Lalande v. Banque Russe, Trib. Comm. Seine, June 29, I932, 6x Clunet 663; Kharon v. Banque Russe, Trib. Civ. Seine, May 20, 1921, 50 Clunet 533; $c f$. Wildenburg v. Comptoir National d'Escompte, Trib. Comm. Seine, Jan. r5, 1934, 6r Clunet 653.

Sweden: By a decision of the Supreme Court of Sweden, the Paris branch of a Russian bank recovered a deposit in a Swedish bank, according to a report in the Rouskoe Slovko of New York, April ro, 1930, noted in Nebolsine, Recovery of Foreign Assets of Nationalized Russian Corporations, 39 Yale L. J. II30, II46 n. 49 (I930).

Denmark: Council of Russian Orthodox Community v. Legation of R.S.F.S.R., Supreme Court, Oct. 22, I925, Ann. Dig. of Int'l. Law Cas. 24 (1925-26), Nebolsine, op. cit. supra II60 n. 98 (I930).

Germany: Ginsberg v. Deutsche Bank, K.G., March 3, I925, I Ostrecht 163 . This decision was reversed on rehearing three years later. Juristische Wochenschrift 1232 (I928). Art. 30 of the E.G.B.G.B. reads: "The application of a foreign law is excluded if the application would contravene good morals, or the purpose of a German law." Nebolsine, op. cit. supra II $59 \mathrm{n} .55$ (r930). The decision both ways turned on the interpretation of that article. After the Treaty of Rapallo, Art. 30 was held inapplicable to the operation of Soviet law. In re Spahn and Son, R. G., May 20, r930, 6r Clunet 447 .

Switzerland: Wilbuschervitz v. Zurich, Trib. Fed., July I3, 1925, 53 Clunet Iı10.

Poland, Latvia, Esthonia: By legislation, Russian corporations were dissolved and their assets distributed to local claimants. Makarov, The Legal Status of Assets Abroad Owned by Nationalized Russian Stock Companies (unpublished paper by A. N. Makarov, former Professor of Law at the University of Petrograd).

44 Carpenter, Jurisdiction over Debts, 3 ז Harv. L. Rev. 905, 907-908 (I9I8).

15 Beidler v. S.C. Tax Commission, 282 U.S. I (I930). See Carpenter, Jurisdiction over

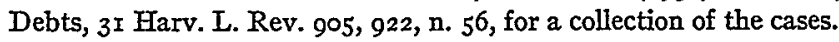

${ }^{46}$ Bluefields Banana Co. v. Board of Assessors, 49 La. Ann. 43, 21 So. 627 (I897); I Beale, Conflict of Laws 304, 588-593, 6 I9 (I935).

${ }_{47}$ Security Savings Bank v. California, 263 U.S. 282 (Ig23).

$4^{8}$ Harris v. Balk, I98 U.S. 215 (I905). 
nections owed to Russian corporations have been held situated abroad for the purpose of ascertaining the effect of the Russian confiscation decrees by courts likewise situated abroad.49 Other formulas for the situs of a debt would place the debt in the Belmont case somewhere outside Russia: the domicil of the debtor, ${ }^{50}$ the place where the original transaction which gave rise to the debt occurred, ${ }^{5 x}$ the places where the debtor can be found, ${ }^{52}$ the places where the debt is recoverable, ${ }^{53}$ the places having the power to control the debtor..$^{54}$

But it is now old learning that a debt is a relation between persons only and consequently has situs only in a fictitious, question-begging sense.55 The cases are not inconsistent-the "situs" depending each time on the purpose for which it was to be determined..$^{6}$ The old view that it is at the domicil of the creditor, based on the maxim mobilia sequnniur personam ${ }^{57}$ has yielded today to the view that one fiction-ascribing situs to any debt ${ }^{58}$-is enough and must be flexible according to the purpose invoked.

The real question, then, for purposes of confiscation is whether the state of the creditor or the state of the debtor has effective control. Accepting the modern doctrine, it can be argued that the situs of a debt for the purpose of taxation is at the creditor's domicil, ${ }^{59}$ that confiscation is like taxation, ${ }^{60}$ that therefore the Soviet government could tax or appropriate the debt to one of its corporations created by a deposit in New York. The distinction between taxation and confiscation, like most distinctions, is one of degree. ${ }^{6 \mathrm{I}}$ That there was confiscation, not mere taxation, by the Soviet government is clear from the intention of the decrees to leave the corporations absolutely nothing. ${ }^{62}$ If, in the Belmont case, a certificate of deposit had been in Russia at the time the confiscation decrees were enforced, the modern tendency to identify the debt with its tangible evidence, even in the case of a non-negotiable chose in action,

49 See cases collected in note 43 , supra.

so Jackson v. Tiernan, 5 La. 485 (I840); Minor, Conflict of Laws 276-277 (Igor).

si Cheshire, Private International Law 352-354 (I935).

52 Harris v. Balk, 198 U.S. 215 (rg04); Rest., Conflict of Laws $\S$ ro8 (r934).

s3 In re Russian Bank for Foreign Trade, [r933] Ch. D. 745.

54 Carpenter, Jurisdiction over Debts, 3 r Harv. L. Rev. 905 (rgr8).

55 I Beale, Conflict of Laws 302 (r935).

${ }^{56}{ }^{6} 6$ Harv. L. Rev. 63 (1902).

57 Story, Conflict of Laws $\$ \S 376-381,397-399$, but $c f . ~ \$ 383$, n. (a) (8th ed. 1883 ); Wharton, Conflict of Laws $\S 36_{3}$ (3d ed. rgo5).

$5^{8}$ I Beale, Conflict of Laws 301-302 (1935).

59 Beidler v. S.C. Tax Commission, 282 U.S. I (I930).

${ }^{60}$ Luther v. Sagor, [I92I] 3 K.B. 532, 559; Nichols v. Coolidge, 274 U.S. 53I, 542-543 (I926); Brushaber v. Union Pacific R.R., 240 U.S. I, 24-25 (19r5).

6x Holmes, J., dissenting in Haddock v. Haddock, 201 U.S. 562, 63 I (xgo6).

${ }^{62}$ See Sokoloff v. National City Bank, 239 N.Y. I58, I45 N.E. 9I7 (1924), where effect of the confiscation decrees was sought to be sustained as a "revolutionary tax." 
for the sake of commercial convenience would provide an argument for locating the debt in Russia. ${ }^{6}$

Control of the owner-creditor may be enough to transfer a debt. Intangible property, such as the beneficial interest in a New York insurance policy, can be transferred by operation of law in the state of domicil of the owner, who was outside the jurisdiction. ${ }^{6}$ Also jurisdiction over shareholder alone is enough to transfer shares of stock in a foreign corporation by confiscatory operation of law..$^{65}$

Further, it is by no means clear that control over the debtor alone is enough. It has been held that Soviet jurisdiction of an American debtor was not sufficient to transfer a contract obligation, performable in Russia, to the Soviet Union, ${ }^{66}$ unless the contract specifically stated Russian law was applicable to all questions about performance of the contract. ${ }^{67}$ Again, much the same result was reached in the state insolvency cases in which discharge of foreign creditors could not be accomplished by control of the state over the debtor..$^{68}$ Finally, it is arguable that Harris $v$. Balk $^{69}$ is distinguishable because the principal debtor is protected-viz., has his debt to the garnishor, or part of it, paid. Of course, it does not follow that some state must always have sufficient control over a given debtor-creditor relation to make an effective confiscation of the debt. Yet such a view seems as plausible in the case of a debt as it does in the case of a chattel whose owner is in another state.

It may be useful to consider whether formal changes in the decrees would affect the result. $7^{\circ}$ Suppose the confiscation decrees are viewed as raising a debt owed by the Russian corporations to the Soviet government for the value of all their property, including that located abroad? In the Belmont case, then, the assignment to the United States was a transfer of a creditor's right against the Russian corporation, and the United States garnisheed the New York debtor to the Russian corporation, where the debtor was found. ${ }^{71}$ The objection

${ }_{63}$ Goodrich, Conflict of Laws 362-364 (I927); Rest., Conflict of Laws $\S 50-53$ (I934).

${ }^{64}$ Carter v. Mutual Life Ins. Co., ro Hawaiian Rep. 559 (1896).

${ }_{5}$ Disconto-Gesellschaft v. U.S. Steel Corp., 267 U.S. 22 (I924).

${ }^{66}$ Sokoloff v. National City Bank, 239 N.Y. I58, I45 N.E. 9 I 7 (I924).

${ }_{67}$ Dougherty v. Equitable Life Assur. Soc., 266 N.Y. 71, 193 N.E. 897 (I934); Perry v. Equitable Life Assur. Soc., 45 T.L.R. 468 (1929).

${ }^{68}$ Phoenix Nat. Bank v. Batcheller, 15 I Mass. 589, 24 N.E. 9 17 (r8go).

${ }^{69} 198$ U.S. 215 (1904). In that case it was held that a judgment in favor of a garnishor against the garnishee, who was temporarily in the state, is entitled to full faith and credit, although the principal debtor was not before the court.

${ }^{70} \mathrm{Had}$ the Soviet Union purported to compensate the Russian corporations, which it did not, would there have been any confiscation, even though compensations were grossly inadequate? When the United States confiscates property, a promise to compensate is implied. Russian Volunteer Fleet v. United States, 282 U.S. 481 (1930).

7x Harris v. Balk, I98 U.S. 215 (xgo4); Kennedy, Garnishment of Intangible Debts, 35 Yale L. J. 689 (I926); I Beale, Conflict of Laws 454-467 (I934); Stumberg, Conflict of Laws Ior-104 (1937); Goodrich, Conflict of Laws 126-r31 (r927); Rest., Conflict of Laws § ro8, Comment b (1934). 
of unfairness to the principal debtor is not available because the Russian corporation, too, can be served in New York..$^{72}$ The question of the validity of the confiscation can in this way be litigated among the three interested parties. The notion that a court would adopt such an interpretation of the confiscation decrees is preposterous enough, but it is interesting to observe how a change of legal language from "confiscation" to "debt" could change legal sympathies.

Suppose the confiscation decrees are viewed as an appropriation of the shares of Russian corporations by the Soviet Union? As between corporation and shareholders, the law of the state of incorporation is final, ${ }^{73}$ although it is said, as between transferor and transferee of shares the law of the place is applicable, ${ }^{74}$ but the law of the state of incorporation can finally control even this question. ${ }^{75} \mathrm{~A}$ transfer of corporate shares can be made in the state of incorporation although the certificates representing the shares are not in the state. ${ }^{76}$ Such a transfer will be upheld abroad. ${ }^{77}$ When a confiscatory transfer has been made abroad, the transferee government is not secure until the state of incorporation upholds the transfer, ${ }^{78}$ which may be refused if the state of incorporation also has legislated confiscation of the shares. ${ }^{79}$ Following the supposed construction of the Soviet decrees the right the United States received by as-

72 I Beale, Conflict of Laws 465-467 (I935); Goodrich, Conflict of Laws r3I (1927); Stumberg, Conflict of Laws ro4 (r937).

73 Hammond v. Hastings, x34 U.S. 40x (1889); Shaw v. Goebel Brewing Co., 202 Fed. 408 (C.C.A. 6th I9I3); Black v. Zacharie \& Co., 3 How. (U.S.) 482 (I845); Boyette v. Preston Motors Corp., 206 Ala. 240, 89 So. 746 (192I); Hunt v. Drug, Inc., 5 Harr. (Dela.) 332, 156 Atl. 384 (I93I); Masury v. Ark. National Bank, 87 Fed. 38I (E.D. Ark. I898), reversed on other grounds 93 Fed. 603 (C.C.A. 8th I899); Moore v. Gennett, 2 Tenn. Ch. 375 ( 1875 ); State v. Dunlap, 28 Idaho 784 , 156 Pac. I I4I (I9 6 ); Husband v. Linehan, I68 Ky. 304, I8I S.W. 1089 (I916); 2 Beale, Conflict of Laws 888-89o, 984-985 (I935); I Beale, op. cit., 303-304; Rest., Conflict of Laws $\S 53(\mathrm{I})$, Comment a, illustrations, $\$ 262$ (I) (1934); Cheshire, Private International Law 367-368 (1935). See Stumberg, Conflict of Laws 336-338 (1937).

74 Mylander v. Chesapeake Bank, 162 Md. 255, I59 Atl. 770 (1932); London, Paris, \& American Bank v. Aronstein, II7 Fed. 6or (C.C.A. 9th I902); Rest., Conflict of Laws $\S 53$ (2), 262(2) Comment d (I934); 3 Beale, Conflict of Laws r498-r5or (I935); Cheshire, Private International Law 368 (I935). Where place of contract to transfer is same as place of incorporation, a court emphasized contract not incorporation. Goewey v. Sanborn, 277 Mass. I68, 179 N.E. 237 (193r).

75 Hunt v. Drug, Inc., 5 Harr. (Dela.) 332, 156 Atl. 384 (I93I); Black v. Zacharie, 3 How. (U.S.) 482 (1845); Moore v. Gennett, 2 Tenn. Ch. 375 (1875); Husband v. Linehan, $168 \mathrm{Ky}$. 304, I8I S.W. 1089 (I9I6); Rest., Conflict of Laws $\$ \$ 53(3), 262(3)$ (1934); 2 Beale, Conflict of Laws 984-985 (I935); Stumberg, Conflict of Laws 338 (1937). Conira: London, Paris \& American Bank v. Aronstein, II 7 Fed. 60I (C.C.A. 9th I902).

${ }^{76}$ Shaw v. Goebel Brewing Co., 202 Fed. 408 (C.C.A. 6th I9I3); Boyette v. Preston Motors Co., 206 Ala. 240, 89 So. 746 (r92I); Masury v. Ark. Nat. Bank, 87 Fed. 38 I (E.D. Ark. 1898), reversed on other grounds, 93 Fed. 603 (C.C.A. 8 th 1899 ).

77 Shaw v. Goebel Brewing Co., 202 Fed. 408 (C.C.A. 6th I9r3).

${ }^{8}$ Disconto-Gesellschaft v. U.S. Steel Corp., 267 U.S. 22 (I924).

79 Beale, Conflict of Laws 888-890 (I935). See Canadian Southern Ry. Co. v. Gebhard, Iog U.S. 527 (I883). 
signment in the Belmont case was that of sole shareholder in the Russian corporation. Subject to claims of creditors, the United States would recover the whole amount of the deposit made by the corporation in New York. The implication of the theory that the Soviet Union acquired the shares of Russian corporation have been disregarded by all the Russian cases, though it has been admitted that the decrees had that effect among others. ${ }^{80}$ The fact that many lines of business were "nationalized" $8 x$ by the Soviet government lends credence to the theory, because to own the stock is to control the corporations.

But except as to chattels subjected to confiscation in the Soviet Union and subsequently brought out, the old slogans of defeated comity and victorious public policy have in fact ruled the cases. ${ }^{82}$ The harsh injustice of uncompensated confiscation is granted, but the courts might more cogently have arrived at much the same result if they had faced more of the problems.

\section{II}

The strong feelings about confiscation undoubtedly also led to a judicial readiness to find that the Russian corporations were not dissolved by the Russian decrees in I9x8. The most apparent means of defeating the claims of the Russian corporations was to show the corporations did not exist for purposes of suing and being sued in the forum. But the arguments employed by the corporations to show their continued existence in spite of the Soviet dissolution decrees were eminently successful. It was contended in many courts of the world that Russian corporations had corporate existence after the Soviet dissolution decrees because the Soviet Union was not recognized politically. This argument was successful before all courts which entertained the question, ${ }^{83}$

${ }^{80}$ Russian C. and I. Bank v. Comptoir d'Escompte de Mulhouse, [1925] A.C. II2, I2I, I24.

${ }^{8 \pm}$ Wohl, The Nationalization of Joint-Stock Banking Corporations in Soviet Russia, 75 U. of Pa. L. Rev. 385, 527, 622 (I927).

${ }^{82}$ Borchard, Confiscations: Extraterritorial and Domestic, 3 I Am. J. Int. Law 675 (I937).

${ }_{3}$ England: Non-recognition caused a British court to behave as though nothing happened in Russia, I9I 7-I92I, Luther v. Sagor, [I92I] I K.B. 456, until recognition compelled reversal of the same case. Luther v. Sagor, [Ig2r] 3 K.B. 532.

France: Prior to recognition, Russian corporations could be sued in French courts, Societé Sago v. Société Russe de Transport et d'Assurance, Trib. Comm. Seine, Nov. 3, I923, 54 Clunet 349; Société X v. Banque Y. Trib. Comm. Seine, Nov. 29, I923, 54 Clunet 350, and Soviet decrees were ignored. Hornstein v. Banque Russo-Asiatique, Trib. Comm. Seine April 15, 1924, 54 Clunet I075; Bounatian v. Société Optorg, Trib. Civ. Seine, Dec. I2, I923, $5 x$ Clunet I33.

United States: The effect of non-recognition upon the standing of the Soviet government was severe; it had no capacity to sue, The Rogdai, 278 Fed. 294 (N.D. Cal. I920) and 279 Fed. I30 (N.D. Cal. I920); The Penza, 277 Fed. 9I (E.D. N.Y. I92I); R.S.F.S.R. v. Cibrario, 235 N.Y. 255 , I39 N.E. 259 (I923); or be sued, Wulfsohn v. R.S.F.S.R., 234 N.Y. 372, I38 N.E. N.E. 24 (1923); and must helplessly observe representatives of the government it succeeded recover a public claim. Lehigh Valley $R$. Co. v. State of Russia, 2I F. (2d) 396 (C.C.A. 2d 1927). But the effect of non-recognition on private litigation was mitigated by judicial recognition of political and economic realities within Soviet territory, Banque de France v. Equita- 
except the highest Swiss court ${ }^{84}$ holding, despite non-recognition of the Soviet Union, that a Russian corporation no longer existed in Switzerland.

Political recognition of the Soviet Union by most countries subtracted one argument from a multitude against application of the Soviet dissolution decrees to Russian corporations. The English courts discovered by inspection of the relevant Soviet decrees that Russian corporations were not dissolved but only liquidated and therefore existent. ${ }^{85}$ Subsequently, they reached the same result by attributing the existence of Russian corporations to registration of branch offices under the Companies Act. ${ }^{86}$ The French courts invented certain requirements ${ }^{87}$ for the establishment of a de facto corporate domicil in France. ${ }^{88}$ Similarly, a German court in 1925 held a Russian bank was a juristic person in

ble Trust Co., 33 F. (2d) 202 (C.C.A. 2d 1929); Salimoff v. Standard Oil Co., 262 N.Y. 220, I93 N.E. 679 (I933); contra, Bourne v. Bourne, 209 App. Div. 4I9, 204 N.Y. Supp. 866 (I924). Generally, the American courts attributed existence to Russian corporations on grounds other than non-recognition, P.M.K. Bank v. National City Bank, 253 N.Y. 23, 170 N.E. 479 (1930); of. Russian Reinsurance Co. v. Stoddard, 240 N.Y. I49, I47 N.E. 703 (1925), and so recognition in I933 did not affect the result. Vladikavkazsky Ry. Co. v. New York Trust Co., 263 N.Y. 369 , 189 N.E. $45^{6}$ (1934). But $f f$. Doughtery v. Eq. Life Assur. Soc., 266 N.Y. 7I, I93 N.E. 897 (1934).

84 Banque Internationale de Commerce de Petrograd v. Hausner, Trib. Fed., Oct. Io, I924, 52 Clunet 488.

${ }^{85}$ Russian C. and I. Bank v. Comptoir d'Escompte de Mulhouse, [1925] A.C. II2; Banque Internationale de Commerce de Petrograd v. Goukassow, [I925] A.C. I5O; Sea Insurance Co. v. Russia Ins. Co., [1924] Lloyd's I. Rep. 308; Woronin v. Huth \& Co., unreported K.B.D. decision, 55 Clunet $75^{6}$ (1928). But of. Lazard Bros. and Co. v. Midland Bank, Ltd., [r933] A.C. 289 .

English courts admitted confiscations had occurred in Russia, White v. Eagle S. and B.

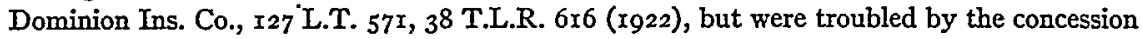
theory of corporate existence giving autocratic power of life and death over corporations to the state of incorporation. Russian and English Bank v. Baring Bros., I46 L.T. 424 (r932).

${ }^{86}$ Section 274, Companies Act (r9o8), 8 Edw. VII, c. 69, \$274. Employers Liability Assur. Corp. v. Sedgwick, Collins \& Co., [I927] A.C. 95; Sabatier v. Trading Co., [r927] r Ch.D. 495. Later, Russian corporations were held to exist for purposes of winding up under the Companies Act of 1929, r9-20 Geo. V.c. 23, $\$ 338(2)$. In re Russian Bank for Foreign Trade, [I933] Ch. D. 745. But Russian corporations do not exist for the purpose of stockholders' suit. Russian and English Bank v. Baring Bros., I46 L.T. 424 (1932).

${ }_{87}$ The corporation must show retention of its powers to sue in French courts, Banque Industrielle de Moscou v. Banque de Pays du Nord, Trib. Civ. Seine, May 2I, I924, 54 Clunet 350, authorization of their representatives, Kamenka v. Cahn, Trib. Comm. Seine, Jan. II, I927, 54 Clunet 362 , and a transfer to France in conformity to Art. 420, Code Civ. de Proc. Société v. Banque Russe, Trib. Comm. Seine, Nov. 26, I925, 54 Clunet 354; Krivitzky v. Banque Russe, Trib. Comm. Seine, Nov. I9, I927, 55 Clunet I32; Karagoulian v. Banque Russe pour le Commerce et l'Industrie, Cour de Paris, May 17, I927, 55 Clunet I3I.

${ }^{88}$ Banque Russo-Asiatique, Trib. Civ. Seine, Mar. 23, I925, 54 Clunet 352; Banque Russe pour le Commerce Etranger, Trib. Civ. Seine, May 3, 1926, 54 Clunet 358; Zélenoff v. Banque de Commerce de Sibérie, Cour d'Appel de Paris, Jan. 3I, I928, 55 Clunet 629; Cie. v. Société d'Assurance Y, Trib. Comm. Seine, May I, I925, 54 Clunet 353; Banque de Sibérie v. Vairon et Cie., Cour de Bordeaux, Jan. 2, 1928, 56 Clunet Ir5, Cour de Cass., July 29, I929, 57 Clunet 
Germany for the purpose of garnishing its debtor, but later reversed the same case. ${ }^{89}$

American courts have endowed internationally foreign corporations with new life at the instance of American creditors in spite of dissolution by the recognized government of the corporate domicil..$^{\circ}$ Dissolution by an unrecognized government, like the Soviet Union until I933, has not disturbed the standing of Russian corporations before the courts in the United States ${ }^{91}$ if properly pleaded. ${ }^{92}$ Their existence has been justified by various legal platitudes. For example, the assertor of the nonexistence of a Russian corporation may be estopped by his behavior in having treated it as a corporate entity. ${ }^{93}$ Or conceding-without considering the legal diffculties-corporate existence in the forum to Russian corporations, some courts refer to the extraterritorial impotency ${ }^{94}$ of the Soviet dissolution decrees resulting from non-recognition of the Soviet Union by the United States. 95 Or they refer to the repugnance of the decrees to the public policy of the forum. ${ }^{6}$ On the other hand, the existence of Russian corporations in the forum has been admirably sustained by sheer judicial ingenuity. Mr. Justice Cardozo in P.M.K. Bank v. National City

680; National City Bank v. Société Renault Russe, Trib. Comm. Seine, July 12, 1929, 56 Clunet II 22, 57 Clunet 400 .

If the Russian corporation could not show a de facto corporate domicile its existence was termed "precarious," Banque Générale v. Jaudon, Trib. Civ. Seine, Dec. 23, I924, 52 Clunet $4 \mathrm{I} 9$, and under an ordinance of Nov. 29, I924, see 52 Clunet $53 \mathrm{I}$ for text, its liquidation was compulsory. Cie. Nord de Moscou v. Phénix Espagnol, Trib. de Paris, June $\mathrm{r}_{3}, \mathrm{x}_{928} 8{ }^{6} 6$ Clunet I19; Vlasto v. Banque Russo-Asiatique, Trib. Comm. Seine, April 26, r922, 50 Clunet 933.

${ }^{89}$ Ginsberg v. Deutsche Banque, K.G. Berlin, Mar. 3, 1925, 10 Ostrecht 163, reversed, Juristische Wochenschrift 1232 ( 1928 ), cited by Nebolsine, The Recovery of the Foreign Assets of Nationalized Russian Corporations, 39 Yale L. J. II3O, II44-45, n. 42-45 (I930).

${ }^{90}$ Hamilton v. Accessory Transit Co., 26 Barb. (N.Y.) 46 (r857); Mitchell v. Banco de Londres y Mexico, I92 App. Div. 720, I83 N.Y. Supp. 446 (1920); Issaia v. Russo-Asiatic Bank, 266 N.Y. 37 , I93 N.E. 543 (1934) as interpreted in Issaia v. Russo-Asiatic Bank, $x_{55}$ Misc. 495, 499-500, 280 N.Y. Supp. 735, 739-74I (1935).

95 P.M.K. Bank v. National City Bank, 253 N.Y. 23, 170 N.E. 479 (I930); see Fletcher, Cyc. Corp. $\$ 858$ I (I933). A dissolved Russian corporation, however, may not be capable of making an effective assignment. Severnoe Securities Corp. v. London \& Lancashire Ins. Co., 255 N.Y. I20, r74 N.E. 299 (I93I).

92 Gumoens v. Equitable Trust Co., 201 N.Y. Supp. 96 (Sup. Ct. I923).

93 Joint Stock Co. of Volgakama Oil \& Chem. Factory v. National City Bank, 240 N.Y. 368, 148 N.E. $55^{2}$ (I925), Wulfsohn v. Russo-Asiatic Bank, II F. (2d) 7 I5 (C.C.A. 9th I926).

94 Hennenlotter v. Norwich Union Fire Ins. Society, I24 Misc. 626, 207 N.Y. Supp. 588 (I924); First Russian Ins. Co. v. Beha, 240 N.Y. 6or, r48 N.E. 722 (I925).

${ }_{95}$ James \& Co. v. Rossia Ins. Co. of America, 247 N.Y. 262, 160 N.E. 364 (I928); Russian Reinsurance Co. v. Stoddard, 240 N.Y. 149, I47 N.E. 703 (1925).

${ }_{96}^{6}$ James \& Co. v. Second Russian Ins. Co., 239 N.Y. 248 , I46 N.E. 369 (r925); Joint Stock Co. of Volgakama Oil \& Chem. Factory v. National City Bank, 240 N.Y. 368, I48 N.E. 552 (I925); James \& Co. v. Rossia Ins. Co., 247 N.Y. 263, I60 N.E. 364 (I928). 
$B a n k^{97}$ grasped the presumption of continued corporate existence and propped it up with a theory of spontaneous corporate existence. $9^{8}$

The courts of this country have never been idle in discovering means of invigorating corporations which are in de facto dissolution in the state of incorporation. 99 If dissolution is admitted, a statute or terms of the dissolution decree can usually be found to extend its existence for the purpose of suing and being sued..$^{\text {xo }}$

The ingenuity expended in avoiding a finding of dissolution in the state of incorporation or, if found, in avoiding its effect suggests that the theory of corporate existence which holds the corporate personality is a revocable concession from the state ${ }^{\text {Ior }}$ is unsatisfactory when the interests of the forum demand continued existence of a corporation. The theory that an association of persons dedicated to certain objects has a natural, spontaneous existence as a corporation ${ }^{\text {ro2 }}$ suits the purposes of capitalistic courts in the Russian cases, but involves the inconvenience of determining when such a corporation begins and ends existence which are not found in the more arbitrary concession theory; if the theory of spontaneous existence were put in general use the difficulties would multiply. Would families, football teams, and political parties be corporations? The United States Supreme Court has long embraced the concession theory of corporate existence, ${ }^{\mathrm{X03}}$ and its latest expression on the question of corporate dissolution expressly adopts that theory. ${ }^{\text {.04 }}$ Adversaries of Russian corporations challenging their existence had strong arguments of authority and convenience, but met with failure. There is no suggestion in the cases that states might have absolute power to create but not necessarily to destroy corporations.

Perhaps the corporate fiction in the Russian cases has been overemphasized

${ }_{97} 253$ N.Y. 23 , I 70 N.E. 479 (1930).

98 See note 102, infra.

99 Brock v. Poor, 216 N.Y. ${ }_{387}$, III N.E. 229 (r915); Speer v. Colbert, 200 U.S. 130 (I905); Folger v. Columbia Ins. Co., 99 Mass. 267 (I868), aff'd 20 Wall. (U.S.) I (1873).

${ }_{200}$ Kelly v. Int'l. Clay Products Co., 29r Pa. St. 383 , I40 Atl. I43 (I928); Lycoming Fire Ins. Co. v. Langley, 62 Md. rg6 (I884); DeWitt Shoe Co. v. Mills, 224 Ala. 500, r40 So. 578 (I932); Hunt v. Columbian Ins. Co., 55 Me. 290 (I867); 6 Fletcher, Cyc. Corp. \$8169 (1933).

${ }^{\text {xor }}$ Dewey, The Corporate Legal Personality, 35 Yale L. J. 655, 666-669 (r926); Cleveland, Status in Common Law, 38 Harv. L. Rev. 1074, ro87-1090 (I925); Machen, Corporate Personality, 24 Harv. L. Rev. 253, 257, 360-362 (I9II); Young, The Legal Personality of a Foreign Corporation, 22 Law Q. Rev. I78 (rg06); 3 Maitland, Collected Papers 308-3I4 (IgIr); 6 Encyc. Soc. Sci. 354-358 (I93I).

${ }^{202}$ Radin, The Endless Problem of Corporate Personality, 32 Col. L. Rev. 643 (I932); Dewey, The Corporate Legal Personality, 35 Yale L. J. 655, 658, 670-673 (1926); Dicey, Law and Opinion in England I53 (I905); 17 Harv. L. Rev. 5 II, 513 (1904); Laski, The Personality of Associations, 29 Harv. L. Rev. 404 (I9I6); 3 Maitland, Collected Papers 3I4-3I9 (IgrI).

${ }^{203}$ Bank of Augusta v. Earle, $\mathrm{r}_{3}$ Pet. (U.S.) 5 I9 $_{9}$ (1839).

${ }^{204}$ Chicago Title \& Trust Co. v. Forty-One Thirty-Six Wilcox Bldg., Corp., 58 S. Ct. 25 (1937). 
by excursions of the courts into theories of corporate existence. The real problem was to provide groups of expropriated individuals a convenient method of suing for their property abroad. They were permitted to use the corporation as plaintiff and defendant as a procedural device in the forum for the convenience of both court and parties. These cases may indicate that the nature of the corporate entity, when it is a question of suing or being sued as distinguished from a question of limited liability, is merely a question of procedure, and hence, under the old formula of the conflict of laws, is to be determined by the law of the forum. ${ }^{\mathrm{x}}{ }^{05}$

\section{III}

With all doubts about the effect of the Soviet confiscation and dissolution decrees on Russian corporate property recoverable abroad resolved in favor of those claiming under the Russian corporations by the courts of the world, the importance of the executive agreement in the Belmont case which reached a different result cannot be ignored.

In view of further explanatory memoranda exchanged between the Soviet Union and the United States in July, I936, there is no question but that claims based on the confiscation decrees were included in the assignment. ${ }^{\text {rot }}$

The court took a desirable step beyond the precedents in treating the executive agreement as a treaty for the purpose of superseding New York law, ${ }^{\text {xo7 }}$ because the added sanction to such agreements will facilitate the business of the Department of State in the conduct of the foreign affairs of the United States. ${ }^{\mathrm{x} 8}$ The exclusion, in the Belmont case, of Russian nationals who have a claim under the corporation from the use of Federal law as a defense to the claim of the United States under the assignment may later be regarded as a dictum. ${ }^{\mathrm{Tog}}$ If not, it modifies a previous decision, Russian Volunteer Fleet $v$. United States, ${ }^{\text {,ro }}$ which held that the United States cannot under the Fifth Amendment confiscate the right to the performance of a contract from alien friends without compensation. The position of the alien friends in that case, however, is distinguishable from the position of the Russian nationals in the Belmont case, because the latter's own government initiated the confiscation

${ }^{{ }^{05}} 3$ Beale, Conflict of Laws, $x 603$ (1935); Rest. Conflict of Laws $\$ 588$ (I935).

${ }^{106}$ Moscow Fire Ins. Co. v. Bank of New York and Trust Co., I6I Misc. 903, 910-9Ir, 294 N.Y. Supp. 648,660 (1937).

${ }^{\text {I07 }}$ An executive agreement is a treaty for the purpose of direct appeal to the United States Supreme Court on a point of construction. Altman \& Co. v. United States, 224 U.S. $5^{83}$ (rgrr).

${ }^{208}$ See Moore, Executive Treaties and Agreements, 20 Poli. Sci. Quart. 385 (I905); Garner, Acts and Joint Resolutions of Congress as Substitutes for Treaties, 29 Am. J. Int. Law 482 (I935).

${ }^{209}$ Claimants who are Russian nationals were not before the court. 301 U.S. 324,332 (1937).

${ }_{2 x 0} 287$ U.S. 48 I (I930). 
to which the United States is a mere auxiliary. Although not expressly mentioned in the Belmont case, it seems likely that non-Russian foreign claimants under the Russian corporation will be protected by the Fifth Amendment as friendly aliens within the rule of the Russian Volunteer Fleet case. Further, it should be noted, that although treaties have been examined and upheld under the Federal Constitution, ${ }^{\text {III }}$ not one has ever been held unconstitutional. ${ }^{\text {II2 }}$ It remains, however, to see how far this judicial patience can be pushed. ${ }^{\mathrm{Ir} 3}$ Conceivably, the Belmont case opens a novel field of power to the executive department of the United States through the use of executive agreements and treaties, a field that has long been subject to the speculations of law writers. ${ }^{\mathrm{r4}}$

The necessity of forbidding palpably unconstitutional acts has sometimes been evaded by the Supreme Court by refuge in the doctrine of political questions, ${ }^{\text {Irs }}$ but this doctrine was not relied on in the Belmont case. The doctrine has been applied only to the negotiation, ${ }^{\mathrm{x} 16}$ violation, ${ }^{\mathrm{xI} 7}$ and termination, ${ }^{\mathrm{xr}}$ of treaties, not to their domestic effect in the United States, ${ }^{1 x 9}$ although treaties, conventions, protocols, and executive agreements are the final products of the higher politics.

${ }^{m r}$ Missouri v. Holland, 252 U.S. 416 (I9I9); United States v. Winans, I98 U.S. 37 (Ig04); United States v. Reid, 73 F. (2d) I53 (C.C.A. 9th 1934).

A treaty that would be unconstitutional if it were a statute is not unconstitutional. United States v. Thompson, 258 Fed. 257 (E.D. Ark. I9I9); United States v. Reid, 73 F. (2d) 153 (C.C.A. gth 1934).

${ }^{\text {Irn }} \mathrm{A}$ treaty has never been declared unconstitutional. Field, Doctrine of Political Questions, 8 Minn. L. Rev. 485,489 , n. 2 I (I924).

${ }^{\mathrm{rr}_{3}}$ See DeGeofroy v. Riggs, I33 U.S. 258, 267 (x889); Asakura v. Seattle, 265 U.S. 332, 34I (1923); The Cherokee Tobacco, II Wall. (U.S.) 6I6, 620-62I (I870), for dicta asserting treaties can be held unconstitutional.

${ }_{174}$ Dowling, Cas. on Const. Law 391, n. 2 (I937).

${ }^{u s}$ Luther v. Borden, 7 How. (U.S.) I ( 1849 ).

${ }^{\prime \prime} 6$ Doe v. Braden, 16 How. (U.S.) 635 ( $\left(88_{53}\right)$.

${ }_{177}$ Taylor v. Morton, 2 Curt. (U.S. C.C.) 454, 46I, aff'd 2 Black (U.S.) 48I (I862); Ware v. Hylton, 3 Dall. (U.S.) I99, 260 (I796).

${ }^{328}$ Ware v. Hylton, 3 Dall. (U.S.) r99, 26I (I796).

${ }^{129}$ Field, The Doctrine of Political Questions in the Federal Courts, 8 Minn. L. Rev. 485, 486-490 (I924). Cf. Cherokee Nation v. State of Georgia, 5 Pet. (U.S.) I (I83I), and Finkelstein, Judicial Self-Limitation, 37 Harv. L. Rev. 338, 35I-352 (I924). Jurisdiction in that case, however, was denied because the Cherokee Nation was not a foreign state and therefore was not a proper party. Chief Justice Marshall expressly left undecided the question whether the equitable relief demanded "savours too much of the exercise of political power to be within the proper province of the judicial department." 5 Pet. (U.S.) I, 20 ( $188_{3} \mathrm{x}$ ). 